\title{
Combination therapy of basal-cell carcinoma in 31-year-old patient with nevoid basal cell carcinoma syndrome - Case study
}

\author{
Adam Borzecki' ${ }^{1}$, Pawel Pilat' ${ }^{2}$, Magdalena Raszewska-Famielec ${ }^{2}$, Joanna Pilat ${ }^{3}$, \\ Monika Dudra-Jastrzebska ${ }^{4}$ \\ ${ }^{1}$ NZOZ Med-Laser Lublin, Poland \\ ${ }^{2}$ Chair and Department of Dermatology, Venerology and Paediatric Dermatology, Lublin, Poland \\ ${ }^{3}$ Independent Public Teaching Hospital No. 1 in Lublin, Poland \\ ${ }^{4}$ Chair and Department of Pathophysiology, Medical University of Lublin, Poland \\ Borzecki A, Pilat P, Raszewska-Famielec M, Pilat J, Dudra-Jastrzebska M. Combination therapy of basal-cell carcinoma in 31-year-old patient \\ with nevoid basal cell carcinoma syndrome - Case study. J Pre-Clin Clin Res. 2016; 10(1): 66-68. doi: 10.5604/18982395.1208193
}

\section{Abstract}

Nevoid basal cell carcinoma syndrome (NBCCS) is a rare genetic disease that is manifested in a number of disorders concerning the skin, skeleton, cardiovascular and nervous systems. Various defects which can be observed at first contact with a patient visiting a dermatologist or dentist may help to diagnose this syndrome. Frequent problems with odontogenic cysts and metastatic basal-cell carcinomas result in patients being under the constant care of a specialist. This short study presents the case of 31-year-old patient with Gorlin-Goltz syndrome treated with combination therapy using CO2 laser and photodynamic therapy.

\section{Key words}

Gorlin-Goltz syndrome, CO2 laser, basal-cell carcinoma, photodynamic therapy

\section{INTRODUCTION}

Nevoid basal cell carcinoma syndrome(NBCCS) was described for the first time in 1960 by an American doctor, a clinical geneticist, as a set of defects with a prevalence of 1:57,000 [1]. This disease is inherited in an autosomal dominant pattern. The reason for the occurrence of numerous lesions of a basal-cell carcinoma character is the total loss of $\mathrm{PTCH}-1$ gene function $[2,3]$. The protein encoded by the $P$ TCH-1 gene acts as a transmembrane receptor and contributes to the regulation of development and proliferation of stem cells in skin, skeleton and central nervous system [1]. Many symptoms of NBCCS have been described to-date and include, among others, defects in the central nervous system (Meningioma, Astrocytoma, cysts in the choroid plexus), optic tract (eyelid microcysts, hypertelorism, congenitalcataracts), urogenital system (ovary cysts and fibromas in females, hypogonadism andgynecomastia in males, L-and U-shaped kidneys), skeleton (too high sinuses aeration within the face, increased skull diameter), as well as in the alimentary and cardiovascular tracts $[4,5,6,7]$. Diagnostics criteria were establish for rapid detection of this disease [8] in which the occurrence of two major criteria, or one major and two minor criteria are essential (Tab. 1.)

Patients suffering from NBCCS require multi-specialist neurological, gynecological, dermatological, and oral care, as well as a maxillofacial surgeon. The main dermatological problems are skin lesions of basal-cell carcinoma (BCC) nature. In order to obtain the best final esthetic effect, these patients require the combination of a few treatment methods during removal of BCC type changes. The methods used

Address for correspondence: Monika Dudra-Jastrzebska, Chair and Department of Pathophysiology, Medical University of Lublin, Jaczewskiego 8b, 20-090 Lublin, Poland

E-mail:monidudra@gmail.com

Received: 13 May 2016; accepted: 16 May 2016
Table 1. Diagnostic criteria in Gorlin-Goltz syndrome

\begin{tabular}{|c|c|}
\hline Major diagnostic criteria & Minor diagnostic criteria \\
\hline $\begin{array}{l}\text { - } \text { basal-cell carcinoma: }>2 \text { or } 1 \text { under } 20 \\
\text { years of age } \\
\text { - } \text { odontogeniccysts } \\
\text { - depressions in skin of hands: } 3 \text { or } \\
\text { more } \\
\text { - } \text { calcification within cerebral falx } \\
\text { - } \text { anomalies of the ribs: split, adherence } \\
\text { - } 1 \text { st degree kinship with the person } \\
\text { with NBCCS syndrome }\end{array}$ & $\begin{array}{l}\text { - } \text { macrocephalia } \\
\text { - cleft palate, hypertelorism, domed } \\
\text { frontal bones } \\
\text { - } \text { high position of shoulder blades, } \\
\text { pectusexcavatum, syndactyly } \\
\text { - } \text { sella turcica multilamellar } \\
\text { calcification } \\
\text { - } \text { ovarianfibroma, } \\
\text { brainmedulloblastoma }\end{array}$ \\
\hline
\end{tabular}

in the therapy of this kind of skin lesions include surgical, $\mathrm{CO}_{2}$ laser, photodynamic lamp with an application of 5 -aminolevulinic acid, and cryotherapy using liquid nitrogen or carbon dioxide.

\section{CASE STUDY}

In February 2011, a male 31-year old patient attended MedLaser for the first time due to numerous disseminated skin lesions within the whole body (Fig. 1). Dermoscopic examination gave rise to the suspicion of changes of a basal cell carcinoma nature, which qualified the patient for surgical therapy. Histopathological examination confirmed the preliminary diagnosis. Additionally, based on morphological features and an interview, the patient was diagnosed with nevoid basal cell carcinoma syndrome. Physical examination demonstrated such features as excessively domed frontal bones, low degree hypertelorism, moderate mental retardation, epidermal cysts of eyelids, as well as fine depressions in the skin of hands.

Because of anomalies within tooth apparatus, the patient was subjected to numerous procedures within the bones of jaw and mandible. In January 2012, extensive oral and 




Figure 1. Basal cell carcinoma

maxillofacial surgery was performed in Independent Public Clinical Hospial No. I (Samodzielny Publiczny Szpital Kliniczny Nr. I - SPSK I) in Lublin, Poland. This procedure involved removal of an abscessed cyst in the vicinity of tooth 37 , extraction of teeth 36 and 37, multichamber cysts from the corner of the right mandible, extraction of gangrenous roots of teeth 16, 17 and 18, as well as removal of a large cyst in the right maxillary sinus. In addition, craniofacial radiographs taken before surgery revealed cerebral falx calcification.

Removal of the first changes using dermatosurgical procedures was not satisfactory and resulted in the formation of keloids (Fig. 2). Therefore, the decision was made to implement a combination therapy using CO2 laser, photodynamic lamp and 5-aminolevulinicacid. In the first stage, the CO2 laser and removal of the changes of a BCC nature by cutting and evaporation was carried out. The procedures were performed under local anesthesia with $1 \%$ lidocaine. The next stage involved the use of a photodynamic lamp and5-aminolevulinicacid (ALA).

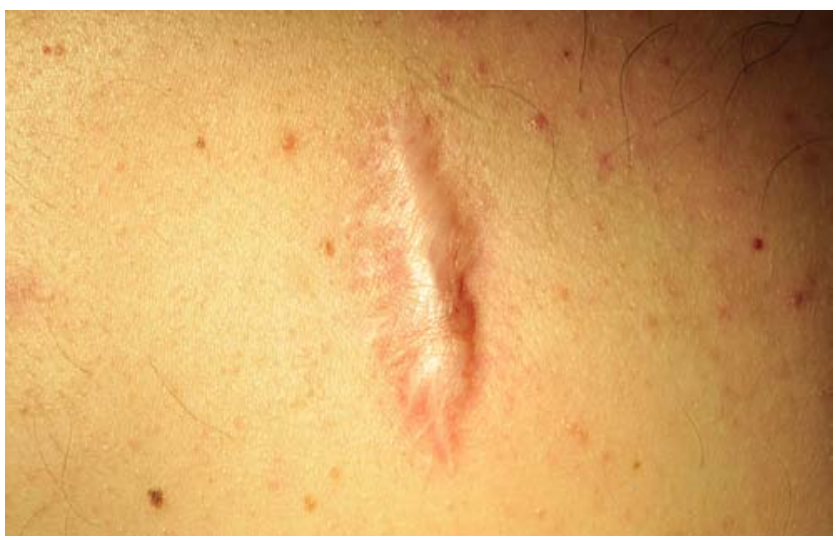

Figure 2. Keloid after surgical procedure

Three days after the laser therapy, 10\% ALA preparation was applied to the lesion under occlusion for 3 hours. This region was then exposed to the photodynamic lamp at $630 \mathrm{~nm}$ wavelength for 20 minutes. The scab covering the wound after laser therapy, had to be removed prior to ALA application, The aim of this procedure was to facilitate the penetration of the preparation and polarized light to the cancer cells, which increased the therapy effectiveness. The patient was subjected to 3 PDT treatments using ALA, each at 3 week intervals.
The therapy carried out this way produced good therapeutic effects while maintaining a satisfactory esthetic result (Fig. 3). The patient ramained under constant dermatological care, and attended regular dermoscopic examinations. The last visit was in June 2015.

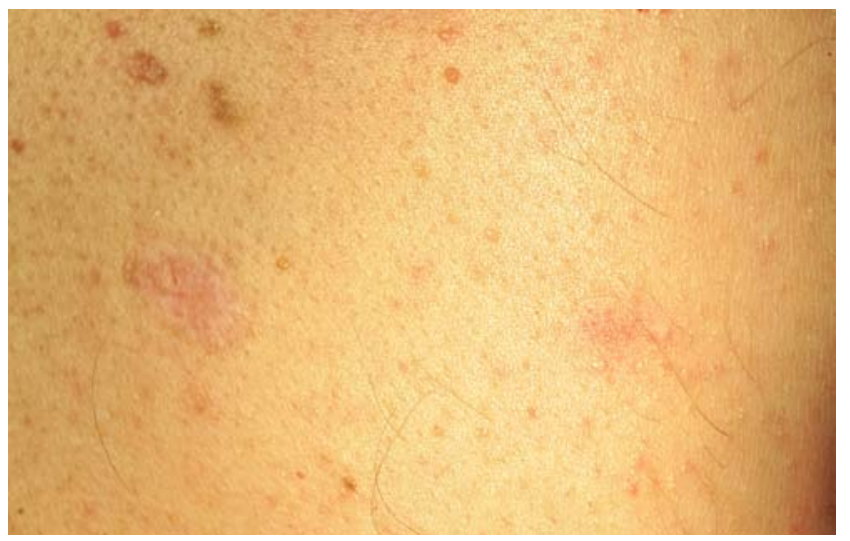

Figure 3. Scar after combination therapy

\section{DISCUSSION}

Currently, there are numerous methods of basal-cell carcinoma therapy. The highest effectiveness is obtained for microsurgical therapy using the Mohs technique which seems to be indispensable in the treatment of lesions in difficult locations (low-riskBCC); in this therapy, less invasive methods do not guarantee successful prognosis $[9,10]$. Unfortunately, the therapy is expensive and difficult to obtain due to the high cost of the equipment, as well as the small number of specialists who use this technique in Poland. Similar esthetic and therapeutic effects at much lower cost are guaranteed by methods such as classic surgery, $\mathrm{CO} 2$ laser, cryosurgery, and photodynamic lamp. It is clear that the choice of therapy method depends on the skills of the dermatologist, available equipment, and the ability to predict the final result achieved by applying the above-mentioned techniques.

The experience of our centre shows that the combination of particular methods additionally contributes to improvement of therapy effectiveness [11]. This particularly relates to $\mathrm{CO} 2$ laser and photodynamic lamp in combination with $10 \% 5$-aminolevulinic acid. Moreover, the combination of these two techniques should be used only in the case of changes of a surface character, confirmed with clinical and histopathological examinations (low-risk BCC). Other forms of basal-cell carcinoma, i.e. nodular, cicatricial and ulcerative, among others, should be treated surgically.

\section{REFERENCES}

1. Burdgorf WHC, Plewing G, Wolff HH, Landhaler M. (ed.). BraunFalcoDermatologia. [In:] Rak podstawnokomórkowy. Reifenberg J, Ruzicka T. Wydawnictwo Czelej, Lublin, 2011: 1378-1379.

2.Dobrzańska A, Ryżko J. (ed.). Pediatria. [In:] Genetyka. KrajewskaWalasek M. Urban \& Partner, Wrocław, 2004: 56-57.

3. Daneswari M, Reddy MSR. Genetic mutations in Gorlin-Goltz syndrome. Indian J Hum Genet. 2013 Jul-Sep; 19(3): 369-372.

4.Szporek B, Kuśnierczyk-Grochowina D, Cieślik T. Badanie cefalometryczne w zespole Gorlina. Dent Med Probl. 2003; 40(2): $411-415$. 
5. Pandeshwar P, Jayanthi K, Mahesh D. Gorlin-Goltz Syndrome. Case Rep Dent. 2012, art 247239.

6. Agrawal A, Murari A, Vutukuri S, Singh A. Gorlin-GoltzSyndrome: Case report of a Rare Hereditary Disorder. Case Rep Dent. 2012, art 475439.

7.Pirshner F, Bastos PM, Contarato GL, Bon Lima Bimbato AC, Filho AC. Gorlin syndrome and bilateral ovarian fibroma. Int J Surg Case Rep. 2012; 3(9): 477-480.

8. Kiwilsza M, Sporniak-Tutak K. Gorlin-Goltz syndrome-a medical condition requiring a multidisciplinary approach. Med Sci Monit. 2012; 18(9): 145-153
9. Stern RS. Cost effectiveness of Mohs Micrographic Surgery. J Invest Dermatol. 2013; 133: 1129-1131.

10. Paoli J, Daryoni S, Wennberg AM, Molnie L, Gillstedt M, Miocic M, Stenquist B. 5-year Recurrence Rates of Mohs Micrographic Surgery for Aggressive and Recurrent Facial Basal Cell Carcinoma. Acta Derm Venereol. 2011 Oct; 91(6): 689-93.

11. Piłat P, Borzęcki A, Krasowska D. Rozległa choroba Bowena twarzy leczenie skojarzone. Przegl Dermatol. 2014; 101: 201-204. 